\title{
Analisis Pengelolaan Sektor Pariwisata Terhadap Pertumbuhan Ekonomi di Kepri Tahun 2015 - 2016
}

\author{
Akhirman \\ Program Studi Manajemen, Fakultas Ekonomi, Universitas Maritim Raja Ali Haji, \\ Tanjungpinang, Kepulauan Riau, Indonesia
}

\begin{abstract}
ABSTRAK : Kepulauan Riau memiliki letak geografis yang strategis antara berbagai negara asing seperti Vietnam, Kamboja, Brunei Darussalam, Malaysia dan Singapura. Maka dari itu, persaingan Kepulauan Riau tidak terpusat pada persaingan nasional, bahkan dibidang internasional lebih sangat diperhatikan karena letak geografis Kepulauan Riau yang lebih dekat dengan berbagai negara asing dibanding dengan Ibukota Negara Indonesia. Juga menjadi wilayah destinasi pariwisata ke 3 setelah Bali dan Jakarta. Namun dalam bidang maritim Kepulauan Riau menduduki peringkat pertama destinasi pariwisata bahari di Indonesia. Dan Kepulauan Riau juga dicadangkan menjadi Gerbang Wisata Bahari Indonesia untuk kancah Internasional.

Pada tahun 2016 perjalanan yang dilakukan penduduk Indonesia yang berasal dari Provinsi Kepulauan Riau yaitu sekitar 3.077.543 dansekitar 58,02 persen melakukan perjalanan dengan tujuan untuk berlibur/rekreasi. Sedangkan, jumlah penduduk Indonesia yang melakukan perjalanan dengan tujuan utama ke Provinsi Kepri, ada sekitar 2.891.123 orang, dan sekitar 59,73 persen datang ke Kepri untuk berlibur/rekreasi (Kementrian Pariwisata RI, 2016).

Jumlah wisatawan mancanegara selama periode januari-Desember 2016 yang datang ke Kepri ada sekitar 1.920.232 orang atau 16,67 persen terhadap total wisman nasional (BPS Kepri,2017). Hal tersebut merupakan potensi yang sangat baik untuk meningkatkan pertumbuhan ekonomi di Provinsi Kepulauan Riau yang harus dikelola dengan baik. Karena kedatangan wisatawan jelas akan menjadi sumber pendapatan bagi Kepri dan mampu menggeliatkan berbagai kegiatan ekonomi sektor-sektor ikutannya.

Penelitian ini bertujuan untuk mengetahui bagaimana pertumbuhan ekonomi sektor pariwisata di KEPRI pada tahun 2015-2016
\end{abstract}

Kata kunci: Pertumbuhan ekonomi, Pariwista

Email Address: 4khirman@gmaill.com

\section{Pendahuluan}

Pada era globalisasi saat ini, sektor pariwisata merupakan industri terbesar dan terkuat dalam pembiayaan ekonomi global. Industri pariwisata kebal akan krisis global, disaat perekonomian global terpuruk, pertumbuhan pariwisata di Indonesia tetap tumbuh. Satu di antara pertumbuhan tersebut karena kontribusi penerimaan devisa
Indonesia dari wisatawan mancanegara (wisman) sepuluh tahun terakhir berada pada kondisi yang sangat baik, meskipun pada tahun 2009 memperoleh devisa sebesar US\$ 6.297,99 juta, jumlah ini lebih rendah dibandingkan penerimaan devisa tahun 2008 yang memperoleh devisa dari wisman sebesar US\$ 7.347,60, pada tahun 2010 dan tahun-tahun selanjutnya terus mengalami 
kenaikan bahkan melampaui target (BPS, 2016).

Peraturan Presiden Republik

Indonesia Nomor 63 tahun 2004 menjelaskan tentang pengawasan dan pengendalian pariwisata pasal 1 ayat 1 yang berisikan definisi Pariwisata yakni "Pariwisata adalah berbagai macam kegiatan wisata dan didukung berbagai fasilitas serta layanan yang disediakan oleh masyarakat, pengusaha, Pemerintah, dan Pemerintah Daerah.

Sebagai informasi, Kepulauan Riau tergolong sebagai provinsi baru di Indonesia yang masih berusia 14 tahun. Walau masih merupakan provinsi baru di Indonesia, pertumbuhan penduduk pada tahun 2016 ini Kepulauan Riau menduduki urutan pertama laju pertumbuhan penduduk terpesat di Indonesia mengalahkan kota-kota lain yang selama ini dipegang oleh kota di pulau Jawa. (Sumber: https://www.bps.go.id/ link Tabel Statis/view/id/1268 diakses pada 10 Desember 2016).

Suku Melayu merupakan penduduk asli dan kelompok suku bangsa yang dominan di KEPRI. Selain itu terdapat juga suku Bugis, Banjar dan Tionghoa yang sudah ratusan tahun berbaur dengan suku Melayu. Menjelang tahun 2000 hingga sekarang suku Jawa, Sunda, Minangkabau dan Batak menjadi suku pendatang yang paling banyak mendatangi KEPRI. Alasan lain mengapa peningkatan penduduk di Kepulauan Riau sangat signifikan yaitu karena pertumbuhan pembangunan Kepulauan Riau juga sangat meningkat dimulai pada tahun 2010. Pembangunan di Kepulauan Riau terus digalakkan di berbagai sektor yaitu sektor industri dan pariwisata. Juga salah satu alasan Kepulauan Riau dipilih sebagai daerah untuk mencari rezeki adalah Kepulauan Riau merupakan daerah yang memiliki UMK tertinggi setelah DKI Jakarta. Berdasarkan SK Gubernur Nomor :1731-1739 Tahun 2015 UMK tertinggi di
Kepulauan Riau yaitu dengan besaran Rp.2.994.111,- dan UMK di Kepulauan Riau akan terus meningkat di tahun 2017. (sumber: http://www.biaya.net/ 2015/11/ daftar-umk-kepri-dan-batam-2016.html diakses pada tanggal 14 Desember 2016.)

Kepulauan Riau memiliki letak geografis yang strategis antara berbagai negara asing seperti Vietnam, Kamboja, Brunei Darussalam, Malaysia dan Singapura. Maka dari itu, persaingan Kepulauan Riau tidak terpusat pada persaingan nasional, bahkan dibidang internasional lebih sangat diperhatikan karena letak geografis Kepulauan Riau yang lebih dekat dengan berbagai negara asing dibanding dengan Ibukota Negara Indonesia. Juga menjadi wilayah destinasi pariwisata ke 3 setelah Bali dan Jakarta. Namun dalam bidang maritim Kepulauan Riau menduduki peringkat pertama destinasi pariwisata bahari di Indonesia. Dan Kepulauan Riau juga dicadangkan menjadi Gerbang Wisata Bahari Indonesia untuk kancah Internasional.

Kepulauan Riau dengan didukung potensi alam yang sangat dimungkinkan untuk menjadi salah satu pusat pertumbuhan ekonomi bagi Republik Indonesia dimasa depan. Apalagi saat ini pada beberapa daerah di Kepulauan Riau tengah diupayakan sebagai pilot project pengembangan Kawasan Ekonomi Khusus (KEK) melalui kerjasama dengan Pemerintah Singapura. (sumber: http://www.kepriprov.go.id/ diakses pada 14 Desember 2016 Tanjungpinang).

\section{Rumusan Masalah}

Berdasarkan uraian di atas, Adapun penelitian ini dapat dirumuskan yaitu sebagai berikut; Apakah ada pengaruh sektor Pengelolaan Sektor Pariwisata terhadap Pertumbuhan Ekonomi di Provinsi Kepulauan Riau khusus Tahun 2015-2016.

\section{Tujuan Penelitian}


Tujuan Penelitian. Tujuan dari penelitian ini adalah menganalisis pengaruh Pengelolaan Sektor Pariwiata Terhadap Pertumbuhan Ekonmi di Provinsi Kepulauan Riau.

\section{Landasan Teori}

\section{Definisi Pariwisata}

Menurut etimologi kata "pariwisata" diidentikkan dengan kata "travel" dalam bahasa Inggris yang diartikan sebagai perjalanan yang dilakukan berkali-kali dari satu tempat ke tempat lain. Atas dasar itu pula dengan melihat situasi dan kondisi saat ini pariwisata dapat diartikan sebagai suatu perjalanan terencana yang dilakukan secara individu atau kelompok dari satu tempat ke tempat lain dengan tujuan untuk mendapatkan kepuasan dan kesenangan (Sinaga, 2010:12).

Pariwisata menurut UU No. 9 Tahun 1990 adalah segala seuatu yang berhubungan dengan wisata termasuk pengusahaan, daya tarik dan atraksi wisata serta usaha-usaha yang berhubungan dengan penyelenggaraan pariwisata.

Menurut pendapta Oka A . Yoeti (Irawan, 2010:11), menjelaskan bahwa kata pariwisata berasal dari bahasa Sansekerta, yatu "...pari yang berarti banyak, berkalikali, berputar-putar, keliling, dan wisata yang berarti perjalanan atau bepergian".

Sementara definisi pariwisata menurut E. Guyer Freuler (Irawan, 2010:11), merumuskan pengertian pariwisata dengan memberikan batasan sebagai berikut : “...Pariwisata dalam arti modern adalah merupakan fenomena dari jaman sekarang yang didasarkan atas kebutuhan akan kesehatan dan pergantian hawa, penilaian yang sadar dan menumbuhakan cinta terhadap keindahan alam dan pada khususnya disebabkan oleh bertambahnya pergaulan berbagai bangsa dan kelas manusia sebagai hasil dari perkembangan perniagaan, industri, serta penyempurnaan dari alat-alat pengangkutan ".

Definisi pariwisata menurut World Tourism Organization (WTO) dalam Marpaung (2000) adalah sebuah aktifitas perjalanan ke suatu tempat ke luar lingkungan mereka sehari-hari dimana dengan tujuan untuk bersenang-senang, beristirahat yang tidak lebih dari setahun di tempat daerah yang dituju. WTO merupakan organisasi internasional yang bertanggungjawab pada bidang pariwisata. WTO mengklasifikasikan wisata menjadi dua yaitu wisatawan mancanegara dan wisatawan domestic. Dimana wisatawan mancanegara merupakan wisatawan yang melakukan perjalanan wisata ke luar Negaranya sendiri, sedangkan wisatawan domestic merupakan wisatawan yang melakukan perjalanan wisata dalam lingkup Negaranya sendiri. Berbeda dengan wisatawan domestic, wisatawan mancanegara kemungkinan akan memeiliki beberapa permasalahan seperti : mata uang, bahasa dan urusan visa (Cooper dkk, 1998).

Dalam Ketetapan MPRS No. 1 Tahun 1960 (dalam Irawan, 2010:11) kepariwisatan dalam dunia modern pada hakekatnya adalah suatu cara untuk memenuhi kebutuhan manusia dalam memberi liburan rohani dan jasmani setelah beberapa waktu bekerja serta mempunyai modal untuk melihat daerah lain (pariwisata dalam negri) atau negara lain (pariwisata luar negri).

\section{Berdasarkan Ketetapan MPRS No. 1}

Tahun 1960 tersebut, sebenarnya sudah menggambarkan bagaiaman hari ini yang disebut sebagai zaman modern semestinya Pariwisata di Indonesia seperti Bali, sudah terdapat di mana-mana sebagai wahana 
pemenuhan keutuhan jasmani sebahagian orang, juga sebagai salah satu sektor ekonomi yang berkontribusi untuk pelakunya dan memberikan kontribusi juga terhadap pembangunan ekonomi nasional.

Pariwisata merupakan suatu perjalanan yang dilakukan oleh satu orang atau lebih dalam waktu yang sementara, dari suatu tempat ke tempat yang lain dengan tujuan bukan untuk berusaha (business) atau bukan untuk mencari nafkah di tempat yang ia kunjungi, melainkan semata-mata sebagai konsumen yang menikmati perjlanan wisata, dimana perjalanan ini bertujuan untuk memenuhi keinginan yang bermacammacam (Yoeti : 1997).

Keinginan yang bermacam-macam yang lain dan tak bukan adalah barangbarang kebutuhan yang diperlukan dalam rangka memenuhi kebutuhan hidupnya tadi. Keinginan untuk mengunjungi suatu tempat yang belum pernah dikunjungi sebelumnya, keinginan untuk melakukan refresing karena penat dalam pekerjaan, adalah salah satu yang mendorong seseorang untuk melakukan wisata. Bagi suatu Negara yang mengembangkan sektor pariwisatanya dengan baik akan mendatangkan banyak para wisatawan, wisatawan yang banyak akan berdampak positif terhadap perekonomian Negara atau daerah yang dikunjungi.

Menurut Pendit (2003), pariwisata merupakan segala sesuatu yang berkaitan dengan wisata, termasuk pengusaha objek wisata, daya tarik wisata serta usaha-usaha yang terkait dengan kepariwisataan. Kepariwisataan menurut UU No.24/1979 diartikan sebgai "segala sesuatu yang berhubungan dengan penyelenggaraan wisata, yaitu keseluruhan kegiatan dunia usaha dan masyarakat yang ditujukan untuk menata kebutuhan perjalanan dan persinggahan wisatawan."
Pengembangan kawasan wisata ini harus memenuhi beberapa kriteria, yaitu : 1). Dalam memutuskan suatu kagiatan pembanguna kawasan wisata harus melalui konsultasi dan sosialisasi terhadap masyarakat, dan apa sudah direncanakan harus berdasarkan persetujuan masyarakata, 2). Tiap keuntungan yang dilakukan dalam pembangunan kawasan wisata harus ada timbalbaliknya kepada masyarakat, namun bukan berbentuk cash money melainkan berbentuk bangunan yang nantinya berguna untuk masyarakat sekitar, 3). Kawasan wisata tidak boleh merusak ekosistem didalam nya atau merusak lingkungan dalam perencanaan pembangunan, serta tidak boleh meninggalkan kebudayaan setempat. Justru dengan mengembangkan kebudayaan, dapat dijadikan brand image atau ikon dari daerah wisata tersebut untuk tujuan menarik para wisatawan, dan dengan pembangunan kawasan wisata tersebut jangan sampai masyarakat merasa tersisihkan.

\section{Jenis Pariwisata}

Menurut Spillane, pariwisata terdiri dari enam jenis, yaitu sebagai berikut :

1) Pariwisata untuk menikmati perjalanan (pleasure tourism), pariwisata ini dilakukan untuk para wisatawan dengan tujuan untuk berlibur atau mencari kesenangan yang baru, mengunjungi suatu tempat yang baru, untuk melihat sesuatu yang baru, serta menikmati hiburan yang ada di kota-kota besar dan ikut serta dalam keramaian pariwisata.

2) Pariwisata untuk rekreasi (recreation tourism) pariwisata ini dilakukan degan tujuan untuk mengisis hari libur mereka atau memanfaatkan ketika seseorang libur bekerja atau melakukan kegiatan mereka sehari-hari, 
bertujuan untuk memulihkan kembali kesegaran jasmani dan rohani serta dalam keramaian atau tempat-tempayt tertentu yang sudah direncanakan.

3) Pariwisata untuk kebudayaan (cultural tourism), pariwisata ini dilakukan wisatawan untuk tujuan mengunjungi suatu Negara atau daerah dengan keinginan megetahui kebudayaan di suatu Negara atau daerah tersebut, mengunjungi pusat kesenian, mengunjungi pusat keagamaan, mempelajari adatistiadat, serta mengunjungi monument atau tempat-tempat yang bersejarah.

4) Pariwisata untuk olah raga (sport tourism), pariwisata ini dilakukan wisatawan untuk tujuan berolah raga atau berpartisispasi dalam olahraga, baik melakukan kegiatan olah raga, maupun manghadiri kegiatan olahraga misalnya mengitu eventevent nasional atau daerah.

5) Pariwisata untuk keperluan bisnis (business tourism) pariwisata ini dilakukan oleh para wisatawan yang secara professional melakukan perjalanan wisata semata-mata untuk keperluan bisnis.

6) Pariwisata untuk konvensi (convention tourism) pariwisata ini dilakukan oleh wisatawan degan tujuan menghadiri konvensi atau konfrensi.

\section{Penawaran Pariwisata}

Menurut Spillane (1987), penawaran pariwisata di bagi menjadi beberapa bagian, yaitu sebagai berikut :

1. Proses Produksi Industri Pariwisata; Pembangunan pariwisata yang sangat maju dalam bidang industri membutuhkan beberapa usaha pendukung, yaitu : media promosi yang dapat memperkenalkan objek wisata, tempat penginapan yang aman dan nyaman, tarnsportasi yang lancar, pemandu wisata (tour guide) yang baik, ramah, sopan santun serta memiliki pengetahuan lebih tentang kepariwisataan, penawaran harga barang dan jasa dengan harga yang bersahabat, pengisisan waktu luang agar tidak membosankan, kondisi kebersihan dan kesehatan lingkungan hidup serta tersedia nya tempat untuk beribadah.

2. Penyediaan Lapangan Kerja; Perkembangkan pariwisata ini membawa pesan positif untuk perekonomian daerah maupun Negara, karena dengan berkembangnya sektor pariwisata di suatu daerah atau negara akan memperluas lapangan pekerjaan. Pembangunan pariwisata yang berkembang tidak hanya membuka lapangan pekerjaan untuk masyarakat setempat, melainkan akan mendorong para pendatang-pendatang baru dari luar daerah maupun luar Negara, karena ketersediaan lapangan kerja tadi.

3. Penyediaan Infrastruktur; Dalam pengembangan industry pariwisata juga memerlukan sarana dan prasarana ekonomi, jalan raya, jembatan, terminal, dermaga pelabuhan, lapangan udara, karena hasil dari pembangunan fisik tersebut akan mendukung pengembangan sektor pariwisata yang ada.

4. Penawaran Jasa Keuangan; Salah satu sumber dari pentingnya pariwisata adalah gaya hidup masyarakat yang masih sangat tradisional. Bagaimana kebiasaan hidup, kebudayaan yang ada, serta adat-istiadat masyarakat menjadi daya tarik tersendiri bagi para wsisatawan yang berkunjung ke suatu daerah. Oleh karena itu pemerintah harus dapat menjadikan masyarakat 
yang memilki gaya hidup tradisional sebagai event yang dapat di jual.

Salah satu isu strategis pembangunan daerah Provinsi Kepulauan Riau adalah pembangunan di bidang pariwisata. Isu-isu strategis pengembangan pariwisata tersebut antara lain:

1) Meningkatnya rata-rata lama tinggal wisatawan di Kepulauan Riau;

2) Meningkatnya jumlah kunjungan wisatawan mancanegara ke Kepulauan Riau;

3) Meningkatnya kunjungan wisatawan nusantara di Kepulauan Riau;

4) Meningkatnya produk domestik bruto di bidang Kepariwisataan;

5) Meningkatnya rata-rata tingkat hunian hotel di Kepulauan Riau.

\section{Metodologi Penelitian}

Menurut Sugiyono (2013:2), Metoe penelitian pada dasarnya merupakan cara ilmiah untuk mendapatkan data dengan tujuan dan kegunaan tertentu. Berdasarkan hal tersebut terdapat empat kata kunci yang perlu diperhatikan yaitu, Cara Ilmiah, data, tujuan dan kegunaan. Sementara itu menurut Darmadi (2013:153), Metode penelitian adalah suatu cara ilmiah untuk mendapatkan data dengan tujuan kegunaan tertentu. Cara ilmiah berarti kegiatan penelitian itu didasarkan pada ciri-ciri keilmuan yaitu, rasional, empiris, dan sistematis.

\section{Tempat dan Waktu}

Penelitian dilaksanakan di Provinsi Kepulauan Riau pada tahun 2015-2016

\section{Sumber Data}

Menurut Arikunto (1998:144), sumber data adalah subjek darimana suatu data dapat diperoleh. Menurut Sutopo
(2006:56-57), Sumber data adalah tempat data diperoleh dengan menggunakan metode tertentu baik berupa manusia, artefak, ataupun dokumen-dokumen. Menurut Moleong (2001:112), pencatatan sumber data melalui wawancara atau pengamatan merupakan hasil gabungan dari kegiatan melihat, mendengar, dan bertanya. Adapun sumber data dalam penelitian ini adalah;

\section{1) Data Primer}

Data primer adalah data yang diperoleh langsung dari sumbernya, meliputi; Infomrasi dari berbagai pihak seperti PKL, Para Wisatawan dalam dan luar negeri. Petugas dians pariwisata dan petugas biro-biro perjalanan wisata.

2) Data Sekunder

Data sekunder dalam penelitian ini adalah data yang diperoleh bukan dari sumber secara langsung dari sumbernya, tetapi dari sumber buku, majalah ilmiah, dokumen-dokumen laporan eknomi regional Bank Indonesia yang terkait dengan judul penelitian.

\section{Hasil dan Pembahasan}

Destinasi Pariwisata atau yang disebut juga dengan daerah tujuan pariwisata, adalah kawasan geografis yang berada dalam satu atau lebih wilayah administratif yang didalamnya terdapat daya tarik wisata, prasarana umum, fasilitas pariwisata, aksebilitas, investasi serta pemberdayaan masyarakat yang saling terkait dan melengkapi terwujudnya kepariwisataan.

Pembangunan Destinasi Pariwisata yang berkualitas, berkelanjutan dan berbasis masyarakat menjadi penting dilakukan untuk memberikan manfaat yang sebesar-besarnya bagi masyarakat dan untuk memenuhi harapan serta ekspektasi wisatawan yang berkunjung ke Kepulauan Riau. Karena itu 
arah kebijakan dan strategi pembangunan khusunya Destinasi Pariwisata Kepulauan Riau.

\section{Sumber Daya Yang Memiliki Potensi}

Sumber daya di sini bercerita tentang sumber daya alam dan sumber daya manusia kepariwistaan. Dari sisi Sumber Daya Alam (SDA), objek dan daya tarik wisata maritim Kepulauan Riau yang tersebar di Kabupaten/Kota dengan keanekaragaman serta keunikan tersendiri. Di KEPRI memiliki banyak objek wisata yang memiliki potensi ekonomi yang besar terhadap pendapatan daerah, contonya seperti; Pantai Trikora, Pulau Abang, Pantai Telunas, Pantai Melur Pulau Galang, Pantai Marina, Gunung Bintan, Batu Ampar dan masih banyak lagi wisata yang ada di Kepulauan Riau ini. Dengan begitu banyaknya objek wisata yang ada di Kepulauan Riau diharapkan dapat meningkatkan penerimaan daerah dari sector pariwisata, baik melalui pajak maupun retribusi daerah.

\section{Manfaat Dan Dampak Ekonomi Pariwisata}

Sektor pariwisata dapat memegang peran penting dalam proses pembangunan ekonomi yang berimbang dan akan berdampak terhadap sektor-sektor lainnya. Pariwisata yang dikelola dengan baik akan menimbulkan manfaat dan juga dampak kepada pemerintah dan juga masyarakat. Majunya industry pariwisata berkantung kepada jumlah wisata yang berkunjung ke daerah atau Negara tersebut dan adanya pertumbuhan ekonomi yang berimbang kepada sektor lain misalnya saja, tersedia penginapan, restoran, serta tawaran dalam paket tour atau transfortasi. Hal itu tidak lepas juga dari dukungan pemerintah dan masyarakat.
Meningkatnya arus wisatawan baik wisatawan mancanegara maupun wisatawan domestic yang berkunjung tentunya akan memberikan manfaat ekonomi bagi penduduk, pengusaha dan pemerintah manfaat ekonomi yang dapat dirasakan oleh penduduk yakni mereka akan mendapatkan peluang atau kesempatan kerja, sehingga akan meningkatkan pendapatan mereka, secara otomastis dapat memperbaiki taraf hidup mereka. Bagi pemerintah ini merupakan hal sangat berdampak positif terhadap pertumbuhan ekonomi daerah dan nasional. Dampak yang timbulkan dalam ekonomi pariwisata ini juga, harus menghadapi timbulnya urbanisasi yang menimbulkan banyak permasalahn social ekonomi di perkotaan. Yang terpenting dalam pengembangan ekonomi di sektor pariwisata ini adalah pembangunan daerah secara regional melalui kegiatan kepariwisataan. Pariwisata memiliki sifat elastisitas positif yang artinya permintaan yang kenaikannya secara proporsional lebih besar dari kenaikan tingkat pendapatan, tetapi tidak hanya berpengaruh terhadap permintaan saja, melainkan factor penawaran juga memainkan peran penting dalam memasarkan produk wisatanya.

Dampak yang dirasakan langsung oleh pemerintah yaitu dampak positif yang diperoleh melalui pajak daerah mapun bukan pajak lainnya. Sektor pariwisata memberikan kontribusi yang besar untuk daera melalui pajak daerah, laba Badan Usaha Milik Daerah, serta pendapatan lain yang sah.

\section{Pertumbuhan Ekonomi Sektor Pariwisata}

Sektor pariwisata merupakan salah satu industri terbesar dan merupakan sektor jasa dengan tingkat pertumbuhan paling pesat di dunia saat ini. Dengan dukungan industri 
teknologi dan informasi, sektor pariwisata diperkirakan mampu menjadi prime mover perekonomian abad 21. Posisi Kepri yang berbatasan langsung dengan beberapa negara tetangga, seperti Singapura dan Malaysia, merupakan modal strategis untuk menarik wisatawan mancanegara untuk datang ke Kepri yang notabenememiliki potensi wisata yang sangat besar, terutama wisata bahari, wisata belanja dan wisata budaya. Kepri telah memenuhi semua kriteria 3A untuk sebuah destinasi wisata, yaitu: Attractiveness (daya tarik), Amenities (fasilitas pendukung/akomodasi) dan Acces (Aksess) (Bank Indonesia, 2017).

Potensi pariwisata Kepri yang bisa dijadikan sebagai tempat tujuan wisata sangatlah luar biasa.Selain Batam, Pulau penyengat, Lagoi dan tempat wisata yang lain, spotwisata Pulau Bawah di Anambas merupakan salah satu pulau terindah se-Asia sebagaimana dinobatkan $\mathrm{CNN}$ pada tahun 2013. Pada tahun yang sama, dalam Anugerah Pariwisata Indonesia (API) Pulau Bawah masuk menjadi salah satu nominator dalam kategori Tempat Menyelam Terpopuler (Most Popular Diving Spot).

Pada tahun 2016 banyaknya perjalanan yang dilakukan penduduk Indonesia yang berasal dari Provinsi Kepulauan Riau yaitu sekitar 3.077.543 dansekitar 58,02 persen melakukan perjalanan dengan tujuan untuk berlibur/rekreasi. Sedangkan, jumlahpenduduk Indonesia yangmelakukan perjalanandengantujuan utama keProvinsi Kepri,adasekitar 2.891 .123 orang, dan sekitar 59,73 persen datang ke Kepri untuk berlibur/rekreasi (Kementrian Pariwisata RI, 2016).Sementara itu,jumlah wisatawan mancanegara selama periode januariDesember 2016 yang datang ke Kepri ada sekitar 1.920 .232 orang atau 16,67 persen terhadap total wisman nasional (BPS
Kepri,2017). Hal tersebut merupakan potensi yang sangat luar biasa, karena kedatangan wisatawan jelas akan menjadi sumber pendapatan bagi Kepri dan mampu menggeliatkan berbagai kegiatan ekonomi sektor-sektor ikutannya.

Penelitian mengenai seberapa besar dampak sektor pariwisata terhadap ekonomi Kepri memang tidak begitu banyak, salah satunya yaitu Analisis Neraca Satelit Sektor Pariwisata tahun 2013.

\section{a. Analisis Neraca Satelit Sektor Pariwisata}

Berdasarkan analisis neraca satelit pada tahun 2013, stimulus perekonomian Kepri yang diciptakan oleh sektor Pariwisata sebesar Rp.8,73 triliun. Angka ini diperoleh dari pengeluaran Wisman Rp.6,23 triliun, Wisnus dari Luar Provinsi Rp.926,26 milyar, wisatawan Kepulauan Riau yang melakukan perjalanan ke luar provinsi (pre+post) Rp.782,99 milyar, Wisnus Lokal Rp.479,20 milyar, wisatawan Kepulauan Riau yang melakukan perjalanan ke luar negeri (pre+post) Rp.241,60 milyar, dan pengeluaran anggaran Pemerintah Daerah untuk promosi pariwisata Rp65,69 miliar. Jumlah ini belum termasuk pengeluaran investasi, serta promosi yang dilakukan dunia usaha untuk keperluan pariwisata dan pemerintah pusat, karena datanya belum tersedia. Dengan mempertimbangkan besarnya potensi dan kontribusi sektor pariwisata terhadap perekonomian Kepri, maka pengembangan sektor pariwisata untuk masa mendatang harus mendapat prioritas terlebih dengan potensi yang dimiliki oleh wilayah Provinsi Kepulauan Riau.

\section{Event pariwisata dan Kunjungan Wisatawan}

Ada beberapa event pariwisata di Kepri pada tahun 2017, di antaranya yaitu 
pada Maret 2017, diadakan Tour De Bintan, berdasarkan rilis perkembangan pariwisata oleh BPS Kepulauan Riau, pada bulan tersebut di Kabupaten Bintan wisatawan manca negara (wisman) naik dari 21.664 orang pada Februari 2017 menjadi 25.198 orang pada Maret 2017 (naik sekitar 16,31 persen).

Pada Juli 2017, di Tanjungpinang dilaksanakan Festival Pulau Penyengat, ternyata wisman yang datang ke Tanjungpinang pada Juli 2017 meningkat dari 8.666 wisatawan menjadi 9.762 orang (meningkat 12,65 \%). Dari keterangan tersebut, terlihat jelas bahwa event pariwisata mempunyai korelasi yang positif terhadap kunjungan wisatawan ke daerah tersebut, dan dengan meningkatnya kunjungan wisatawan, hal ini akan menghasilkan efek multiplier terhadap sektor ikutannya.

Sektor pariwisata melibatkan hampir semua sektor ekonomi baik yang tergolong tourism characteristic industry seperti hotel dan restoran maupun tourism connected industry yaitu industri yang sepintas tak berkaitan dengan industri pariwisata namun sebagian demand nya berasal dari pariwisata. Dengan kata lain,sektor yang terkait dan menerima dampak multiplier dari pariwisata sungguh tak terbilang dan apabila dikelola dengan baik, jelas akan mampu mengangkat kembali pertumbuhan ekonomi di Kepulauan Riau.

\section{Kesimpulan}

\section{Kesimpulan}

Pariwisata merupakan suatu kegiatan yang secara langsung menyentuh dan melibatkan masyarakat, sehingga membawa berbagai dampak terhadap masyarakat setempat. Bahkan pariwisata dikatakan mempunyai energi pendorong yang luar biasa, yang mampu membuat masyarakat setempat mengalami metamorfosa dalam berbagai aspeknya.

Berdasarkan deskripsi hasil penelitian dan hasil pembahasan yang telah dikemukakan pada bab-bab sebelumnya, maka penulis dapat menarik kesimpulan dampak ekonomi yang terjadi terhadap masyarakat sekitar dapat dikatakan cukup meningkat dari tahun sebelumnya.

Dari hal tersebut munculah dampak yang ditimbulkan sektor pariwisata sebagai pengembangan ekonomi lokal adalah sebagai berikut :

1. Pegelolaan sektor pariwisata yang baik merupakan bentuk usaha yang dilakukan oleh pemerintah, swasta, dan masyarakat lokal untuk memaksimalkan pendayagunaan dari potensi wisata yang terdapat di suatu daerah. Perkembangan ekonomi lokal tersebut biasanya ditandai dengan munculnya usaha-usaha kecil sebagai multiplier effect dari adanya bentuk kegiatan wisata tersebut yang pada akhirnya dapat meningkatkan kesejahteraan masyarakat bila dikelola dengan baik

2. Diberikannya bantuan kepada masyarakat, mereka dapat memiliki pekerjaan dan pendapatan yang cukup untuk kelangsungan kehidupan seharihari karena masyarakat dapat mengelola bantuan tersebut dengan baik walaupun dengan selalu adanya monitoring di lokasi obyek tersebut demi kelancaran bantuan yang di berikan dapat terprogram dengan baik. Tingkat pendidikan tentang pengetahuan tentang kepariwisataan lebih di mengerti oleh masyarakat sekitar obyek. 


\section{Saran}

Sesuai dengan uraian yang telah di kemukakan pada bab-bab sebelumnya penulis memberikan asumsi berupa saran bagi pimpinan Dinas Pariwisata untuk lebih giat dalam pengembangan serta mengelola obyek wisata secara optimal. Diharapkan juga dapat menjaga serta melestarikan kawasan pariwisata.

Bagi pihak masyarakat tetaplah selalu menjaga dan memperhatikan lingkungan agar tetap bersih sehingga wisatawan akan merasa nyaman terutama masyarakat yang ada di sekitaran objek wisata, sehingga makin banyak wisatawan yang tertarik berkunjung ke KEPRI.

Pihak Dinas juga kiranya dapat memperhatikan dan juga harus mampu bekerja sama dengan lembaga pendidikan, peneliti atau siapa saja yang membutuhkan bantuan dan informasi-informasi, sehingga merasa terkesan yang baik saat mengharapkan informasi tentang obyek wisata yang mungkin bisa membantu pembangunan pengembangan obyek wisata tersebut, serta selalu mengupdate informasi di internet, karena informasi tentang pariwisata belum begitu optimal dan yang pastinya bagi wisatawan yang ingin berkunjung bisa melihat bagaimana obyek wisata ini sebelum datang berkunjung ke lokasi.

\section{Daftar Pustaka}

Ari, Wibowo. 2018, "Kebijakan Dinas

Pariwisata Provinsi Kepulauan Riau Dalam

Pembangunan Pariwisata

Berbasis Kemaritiman”, Fakultas Ilmu

Sosial dan Ilmu Politik,

Universitas Maritim Raja Ali Haji.
Badan Pusat Statistik, 2016, Kajian Pertumbuhan Ekonomi Provinsi Kepulauan Riau 2012-2016, Kepulauan Riau

Bank Indonesia, 2017, Kajian Ekonomi dan Keuangan Regional Provinsi Kepulauan Riau Februari 2017, Kepulauan Riau

BPS, Kepri, 2017. Data jumlah Wisatawan ke Provinsi Kepualaun Riau.

Kementerian Pariwisata RI, 2016, Data Perjalanan Wisatawan ke Provinsi

Kepulauan Riau.

http://tanjungpinangpos.id/sektor -pariwisata-kuda-hitam-pembangkitperekonomian-kepri/

Peraturan Presiden Republik

Indonesia Nomor 63 tahun 2004 tentang pengawasan dan pengendalian pariwisata pasal 1 ayat 1 .

Sinaga, Supriono. 2010. Potensi dan Pengembangan Objek Wisata Di Kabupaten Tapanuli Tengah. Kertas Karya. Program DIII Pariwisata. Universitas Sumatera Utara. 